\title{
The tetranuclear copper active site of nitrous oxide reductase: the $\mathrm{CuZ}$ center
}

\author{
Simone Dell'Acqua $\cdot$ Sofia R. Pauleta $\cdot$ \\ Isabel Moura $\cdot$ José J. G. Moura
}

Received: 9 August 2010/Accepted: 3 January 2011/Published online: 15 January 2011

(C) SBIC 2011

\begin{abstract}
This review focuses on the novel $\mathrm{CuZ}$ center of nitrous oxide reductase, an important enzyme owing to the environmental significance of the reaction it catalyzes, reduction of nitrous oxide, and the unusual nature of its catalytic center, named CuZ. The structure of the $\mathrm{CuZ}$ center, the unique tetranuclear copper center found in this enzyme, opened a novel area of research in metallobiochemistry. In the last decade, there has been progress in defining the structure of the $\mathrm{CuZ}$ center, characterizing the mechanism of nitrous oxide reduction, and identifying intermediates of this reaction. In addition, the determination of the structure of the $\mathrm{CuZ}$ center allowed a structural interpretation of the spectroscopic data, which was supported by theoretical calculations. The current knowledge of the structure, function, and spectroscopic characterization of the $\mathrm{CuZ}$ center is described here. We would like to stress that although many questions have been answered, the $\mathrm{CuZ}$ center remains a scientific challenge, with many hypotheses still being formed.
\end{abstract}

Keywords Copper proteins $\cdot \mathrm{CuZ}$ center $\cdot$ Nitrous oxide reductase $\cdot$ Denitrification

S. Dell'Acqua and S.R. Pauleta contributed equally to this work.

S. Dell'Acqua · S. R. Pauleta · I. Moura · J. J. G. Moura ( $ه)$ REQUIMTE/CQFB, Departamento de Química,

Faculdade de Ciências e Tecnologia,

Universidade Nova de Lisboa,

2829-516 Caparica, Portugal

e-mail: jose.moura@dq.fct.unl.pt

\section{Introduction}

Copper-containing proteins and enzymes play crucial roles in metabolic and cellular processes in both eukaryotes and prokaryotes [1-4], such as electron transport (plastocyanin, azurin, stellacyanin) [5-7], in oxygen transport in arthropods and mollusks (hemocyanin) [8,9], in the reduction of $\mathrm{O}_{2}$ to $\mathrm{H}_{2} \mathrm{O}$ [cytochrome $c$ oxidase (COX), laccase, ascorbate oxidase] [10], in the reduction of $\mathrm{O}_{2}$ to $\mathrm{H}_{2} \mathrm{O}_{2}$ (amine oxidase, galactose oxidase) $[11,12]$, in the oxidation of various organic substrates (tyrosinase, methane monooxygenase, dopamine $\beta$-hydroxylase) [12, 13], and in the reduction of small inorganic molecules [nitrite reductase, nitrous oxide reductase $\left(\mathrm{N}_{2} \mathrm{OR}\right)$, superoxide dismutase] [14-16].

Most of the copper centers present in these proteins can be divided into three classes (type 1, type 2, and type 3) [17-19]. However, recently new protein structures and spectroscopic data have led to the identification of two novel copper sites that cannot be classified into the initial division.

One is the CuA center, a binuclear copper center, different from the binuclear type 3 copper center. In the $\mathrm{CuA}$ center, each copper ion is coordinated by two cysteine and two histidine residues, whereas the third ligand is the carbonyl oxygen of a methionine or a glutamate residue [7] (Fig. 1, Panel A).

The $\mathrm{CuA}$ center has been identified in $\mathrm{COX}$ and $\mathrm{N}_{2} \mathrm{OR}$ (Fig. 1, Panel A), where it plays the role of an electron transferring center, accepting electrons from small electron transfer proteins and transferring them to the catalytic site, which is usually in another domain of the enzyme [7].

The last novel biological copper center to be identified and characterized was the $C u Z$ center, a $\mu 4$-sulfide bridged tetranuclear copper center, which is the catalytic site of 


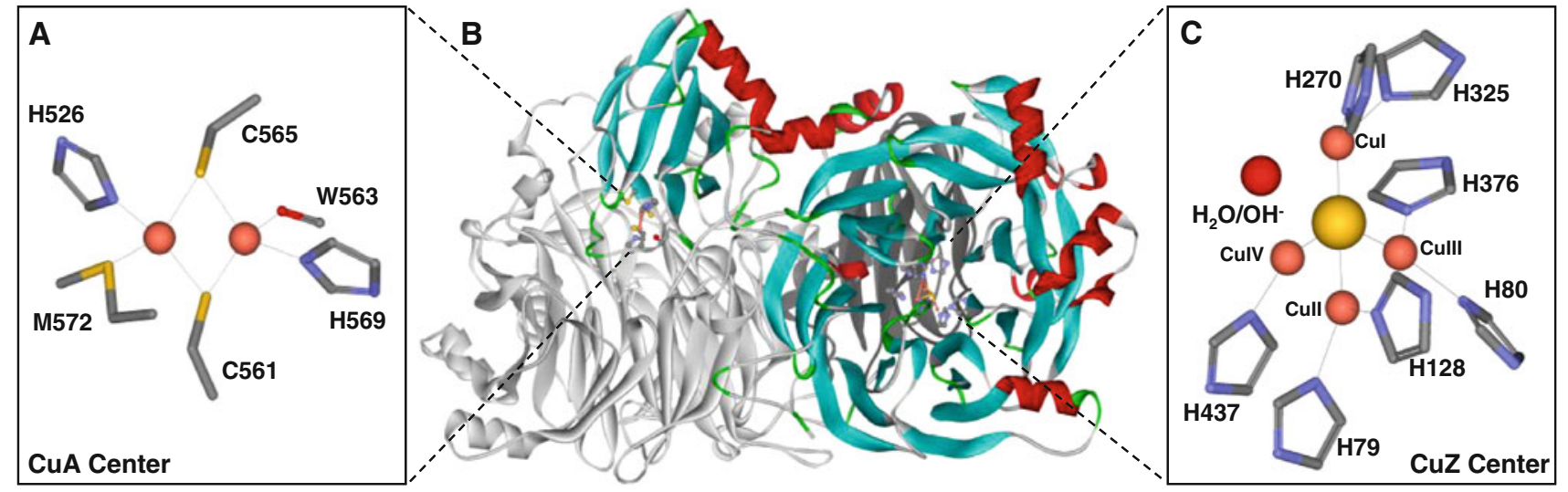

Fig. 1 Representation of the Paracoccus denitrificans nitrous oxide reductase functional dimer. The dimer of nitrous oxide reductase is colored according to the subunit. One monomer is colored light gray, whereas the other is colored by secondary structure $(B)$. The $\mathrm{CuA}$

$\mathrm{N}_{2} \mathrm{OR}$ (Fig. 1, Panel C). This review focus on the current views on the $\mathrm{CuZ}$ center structure, spectroscopic characteristics, and catalytic properties.

The $\mathrm{CuZ}$ center is responsible for the catalysis of the two-electron reduction of nitrous oxide $\left(\mathrm{N}_{2} \mathrm{O}\right)$ to nitrogen and water, the final step of the denitrification pathway $[3,20,21]$ :

$$
\begin{aligned}
& \mathrm{N}_{2} \mathrm{O}+2 \mathrm{H}^{+}+2 \mathrm{e}^{-} \rightarrow \mathrm{N}_{2}+\mathrm{H}_{2} \mathrm{O}\left[E^{\prime^{\circ}}(\mathrm{pH} 7.0)=+1.35 \mathrm{~V} ;\right. \\
& \left.\Delta G^{\mathrm{o}^{\prime}}=-339.5 \mathrm{~kJ} \mathrm{~mol}^{-1}\right] .
\end{aligned}
$$

The catalysis of this reaction plays an important environmental role, owing to the fact that $\mathrm{N}_{2} \mathrm{O}$ is a potent greenhouse gas. Moreover, the emission of this gas into the atmosphere was enhanced in the last century through the intensification of agriculture, the so-called green revolution, which increased the presence of nitrogen in soil through the application of synthetic nitrogen-based fertilizers [22, 23]. Therefore, a better understanding of $\mathrm{N}_{2} \mathrm{OR}$ will soon have both an environmental and a biotechnological impact.

The key role of copper in the respiration of $\mathrm{N}_{2} \mathrm{O}$ was identified by Iwasaki et al. [24, 25], who demonstrated that the presence of this metal in the growth medium was essential for anaerobic growth when $\mathrm{N}_{2} \mathrm{O}$ was used as an electron acceptor. The first report of a $120-\mathrm{kDa}$ coppercontaining protein isolated from a denitrifying pseudomonad came from Matsubara and Zumft [26], which also proved that copper ions play an important role in the biosynthesis of $\mathrm{N}_{2} \mathrm{OR}$ in this denitrifying bacterium. These authors identified this protein as $\mathrm{N}_{2} \mathrm{OR}$, by demonstrating that it could reduce $\mathrm{N}_{2} \mathrm{O}$ to $\mathrm{N}_{2}$ in a in vitro assay that used methylviologen, hydrogen, and clostridial hydrogenase as electron-donating systems [27].

Since $\mathrm{N}_{2} \mathrm{OR}$ was first isolated from Pseudomonas stutzeri (formerly Pseudomonas perfectomarina) [28, 29], it
(A) and $\mathrm{CuZ}(C)$ centers have their copper ligands colored according to the element and the coppers ions in the $\mathrm{CuZ}$ center are numbered I, II, III, and IV. The figure was created with DSViewer Pro 5.0 (Accelrys) using 1FWX

has been purified and characterized from other bacterial sources, such as Rhodobacter capsulatus (formerly Rhodopseudomonas capsulate) [30], Rhodobacter sphaeroides f. sp. denitrificans [31], Paracoccus denitrificans [32], Wolinella succinogenes [33], Flexibacter canadensis [34], Achromobacter cycloclastes [35], Pseudomonas aeruginosa [36], Paracoccus pantotrophus (formerly Thiosphaera pantotropha) [37], Thiobacillus denitrificans [38], Alcaligenes xylosoxidans [39, 40], Pseudomonas nautica (renamed Marinobacter hydrocarbonoclausticus) [41], and more recently Hyphomicrobium denitrificans [42].

\section{The history of the $\mathrm{CuZ}$ center}

Although the presence of the $\mathrm{CuZ}$ center was proposed about 20 years ago [43], our knowledge of its chemistry is still scarce and owing to its characteristics it represents a fascinating chapter in the field of bioinorganic chemistry.

The presence of two distinct copper sites in $\mathrm{N}_{2} \mathrm{OR}$ was clear from the first isolation of the enzyme in 1982 [27]. At that time the $\mathrm{CuA}$ center had already been observed in COX [44], and was identified as being a binuclear copper site, able to accept electrons from small electron donor proteins [45].

The similarity between the $\mathrm{CuA}$ centers in $\mathrm{COX}$ and $\mathrm{N}_{2} \mathrm{OR}$ was first demonstrated by Kroneck et al. [46, 47] using a multifrequency EPR approach. These studies were followed by the study of Jin et al. [48], who studied the copper centers in $\mathrm{N}_{2} \mathrm{OR}$ by electron spin echo spectroscopy and presented further evidence for the similarity between the $\mathrm{CuA}$ center in the two enzymes. This similarity was also shown by magnetic circular dichroism (MCD) [49, 50] and extended X-ray absorption fine structure (EXAFS) studies, as the curve-fitted copper EXAFS results for $\mathrm{N}_{2} \mathrm{OR}$ 
are strikingly similar to those for COX [50-52]. Finally, the identification of a set of potential copper ligands in the C-terminal domain of $\mathrm{N}_{2} \mathrm{OR}$, which matched the ones of the $\mathrm{CuA}$ center in $\mathrm{COX}$, was crucial to establish that the $\mathrm{CuA}$ center, initially believed to be unique to $\mathrm{COX}$, is also present in $\mathrm{N}_{2} \mathrm{OR}[53,54]$ (Fig. 1, Panel A).

The other copper center of $\mathrm{N}_{2} \mathrm{OR}$ was detected when the enzyme was reduced with dithionite. This copper center was clearly different from a $\mathrm{CuA}$ center (which has absorption bands at 480,540 , and $780 \mathrm{~nm}$ ) or a type 1 copper center (with an absorption maximum at $600 \mathrm{~nm}$ ), as the dithionite-reduced form is characterized by a $640-\mathrm{nm}$ band in the visible spectrum. Another distinctive feature is its axial EPR signal, with $g$ values at 2.16-2.18 and 2.04-2.06 with a broad four-line hyperfine splitting pattern [28].

Since it was considered that the $\mathrm{CuA}$ center was the electron transfer site (like in COX), this other copper center was proposed to be the catalytic center, and was named by Farrar et al. [43] as the CuZ center. At that time, the $\mathrm{CuZ}$ center was proposed to be a binuclear copper center with properties different from those of either a type 3 copper center or a $\mathrm{CuA}$ center.

This new copper center was characterized by resonance Raman spectroscopy and the results were interpreted as indicating the presence of a highly covalent thiolate $\left(\mathrm{Cu}^{2+}-\mathrm{Scys}^{-} \leftrightarrow \mathrm{Cu}^{+}-\right.$Scys$\left.\cdot\right)$ in the dithionite-reduced enzyme $[49,55]$.

These results as well as other spectroscopic characterization using absorption, EPR, and MCD spectroscopies led to the proposal that the $\mathrm{CuZ}$ center has a thiolate coordination supported by cysteine residues, akin to the $\mathrm{CuA}$ center. However, the primary sequence of $\mathrm{N}_{2} \mathrm{OR}$ did not have any conserved cysteine residues, besides the ones in the $\mathrm{C}$-terminal $\mathrm{CuA}$ domain that could not be involved in the coordination of a second thiolate binuclear center. Nevertheless, Zumft [3] noticed the presence of eight conserved histidine residues in the primary sequence of the enzyme. This observation, combined with spectroscopic and mutagenesis data, led to the revision of the nature of the $\mathrm{CuZ}$ center and to the proposal that the $\mathrm{CuZ}$ center is coordinated by multiple histidine residues [56]. This study also pointed out that there are more than two copper ions in the catalytic center of $\mathrm{N}_{2} \mathrm{OR}$, showing that the $\mathrm{CuZ}$ center is more complex than a simple binuclear type 3 copper center.

Indeed, later the crystal structure of $\mathrm{N}_{2} \mathrm{OR}$ demonstrated that this prediction was correct, and that the $\mathrm{CuZ}$ center is in fact a unique center in bioinorganic chemistry (Fig. 1, Panel C) [57, 58].

The structure of the $\mathrm{CuZ}$ center opened a new chapter in the area of biological metal clusters, giving a structural basis for the interpretation of the spectroscopic data, and also providing the possibility to analyze these data using theoretical calculations [59].

\section{$\mathrm{X}$-ray structure of the $\mathrm{CuZ}$ center}

The fascinating and unexpected structure of the tetranuclear $\mathrm{CuZ}$ center was revealed by the resolution of the three-dimensional structure of $\mathrm{N}_{2} \mathrm{OR}$ from Pseudomonas nautica at $2.4 \AA$, in 2000 [57]. However, the electron density bridging the four copper ions in the tetrahedron that corresponds to the inorganic sulfur was initially attributed to an oxygen atom. The bridging sulfur ion was only unambiguously identified after the detection of resonance Raman frequency lines associated with sulfur [60], combined with the high-resolution structure of Paracoccus denitrificans $\mathrm{N}_{2} \mathrm{OR}$ at $1.6 \AA$ and elemental analysis that proved the existence of an inorganic sulfur [58, 61].

In fact, the $\mathrm{CuZ}$ center is a distorted tetrahedron of copper ions bridged by a sulfide ion $\left(\mathrm{Cu}_{4} \mathrm{~S}\right)$ (with the copper ions being labeled as $\mathrm{Cu}_{\mathrm{I}}, \mathrm{Cu}_{\mathrm{II}}, \mathrm{Cu}_{\mathrm{III}}$, and $\mathrm{Cu}_{\mathrm{IV}}$ in Fig. 1, Panel C), that is, bound to the protein via the nitrogen atoms of seven well-conserved histidine residues, with five of them coordinating the copper ions through the $\mathrm{N} \varepsilon 2$ atoms (His-80, His-128, His-270, His-325, and His376 in Pseudomonas nautica), and the other two through the $\mathrm{N} \delta 1$ atoms (His-79 and His-437 in Pseudomonas nautica) (Fig. 1, Panel C).

The $\mathrm{Cu}_{4} \mathrm{~S}$ cores of the $\mathrm{CuZ}$ center from all the available $\mathrm{N}_{2} \mathrm{OR}$ structures are very similar both in symmetry and in interatomic distances (Fig. 2). This cluster has an approximate $C_{s}$ symmetry with $\mathrm{Cu}_{\mathrm{I}}-\mathrm{S}-\mathrm{Cu}_{\mathrm{II}}$ defining the mirror plane. The average distance of the $\mathrm{Cu}-\mathrm{S}$ bonds is approximately $2.3 \AA$ and the $\mathrm{Cu}-\mathrm{Cu}$ distances vary from 2.6 to $3.4 \AA$. The $\mathrm{Cu}_{\mathrm{I}}-\mathrm{S}-\mathrm{Cu}_{\mathrm{II}}$ angle is close to $160^{\circ}$, whereas all other $\mathrm{Cu}-\mathrm{S}-\mathrm{Cu}$ angles are approximately orthogonal.

The nature of the bridging ligand between $\mathrm{Cu}_{\mathrm{I}}$ and $\mathrm{Cu}_{\mathrm{IV}}$, the proposed binding site for the substrate $\mathrm{N}_{2} \mathrm{O}$, is still unclear and the object of debate. In the first Pseudomonas nautica $\mathrm{N}_{2} \mathrm{OR}$ structure (2.4- $\AA$ resolution), the electronic density was modeled as two hydroxyl groups between $\mathrm{Cu}_{\mathrm{I}}$ and $\mathrm{Cu}_{\mathrm{IV}}$ [57], whereas after a revision of the same structure, the bridging ligand was proposed to be an oxygen [58] (Fig. 2, Panel A). However, in Paracoccus denitrificans $\mathrm{N}_{2} \mathrm{OR}$ (1.6- $\AA$ resolution), the bridging ligand, between $\mathrm{Cu}_{\mathrm{I}}$ and $\mathrm{Cu}_{\mathrm{IV}}$ of the $\mathrm{CuZ}$ center, was proposed to be either a water molecule or a hydroxyl group [61] (Fig. 2. Panel B), and in the Achromobacter cycloclastes $\mathrm{N}_{2} \mathrm{OR}$ structure (1.9- $\AA$ resolution) the pocket between $\mathrm{Cu}_{\mathrm{I}}$ and $\mathrm{Cu}_{\text {IV }}$ of the $\mathrm{CuZ}$ center can accommodate both a water molecule and a hydroxyl group [62] (Fig. 2, Panel C). The structure of Achromobacter cycloclastes $\mathrm{N}_{2} \mathrm{OR}$ was 
Fig. 2 Comparison between the $\mathrm{CuZ}$ center from the

Pseudomonas nautica $(A)$,

Paracoccus denitrificans (B), and Achromobacter cycloclastes $(C, D)$ nitrous oxide reductases. An oxygen atom, represented as a red sphere, is located between $\mathrm{Cu}_{\mathrm{I}}$ and $\mathrm{Cu}_{\mathrm{IV}}$ of the

Pseudomonas nautica and

Paracoccus denitrificans $\mathrm{CuZ}$ centers. In the $\mathrm{CuZ}$ center of a pink form of Achromobacter cycloclastes nitrous oxide reductase $(C)$, a water molecule and a hydroxide are present between $\mathrm{Cu}_{\mathrm{I}}$ and $\mathrm{Cu}_{\mathrm{IV}}$. In Panel $D$ the inhibited form of this enzyme with an iodide molecule bridging $\mathrm{Cu}_{\mathrm{I}}$ and $\mathrm{Cu}_{\mathrm{IV}}$ is represented. The ligands of the copper ions are colored according to the element. The figure was created with DSViewer Pro 5.0 (Accelrys) using 1QNI $(A)$, 1FWX $(B)$, $2 \mathrm{IWF}(C)$, and $2 \mathrm{IWK}(D)$
Pseudomonas nautica

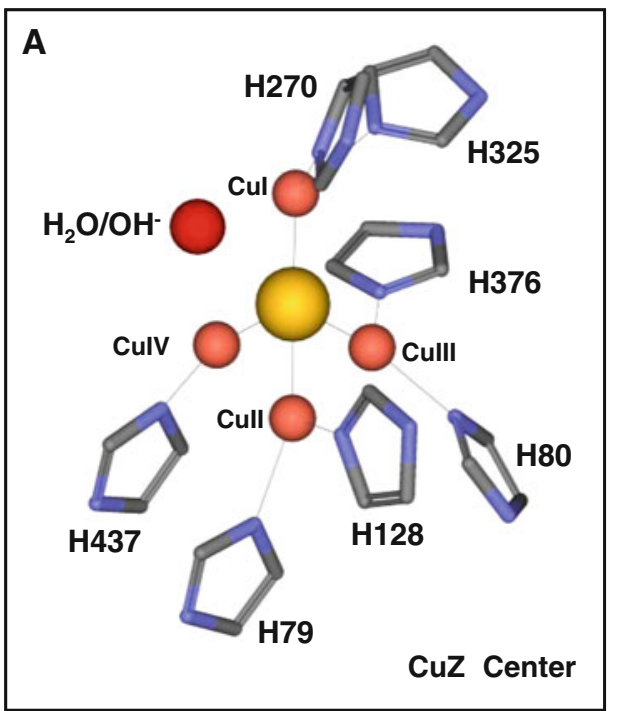

Achromobacter cycloclastes

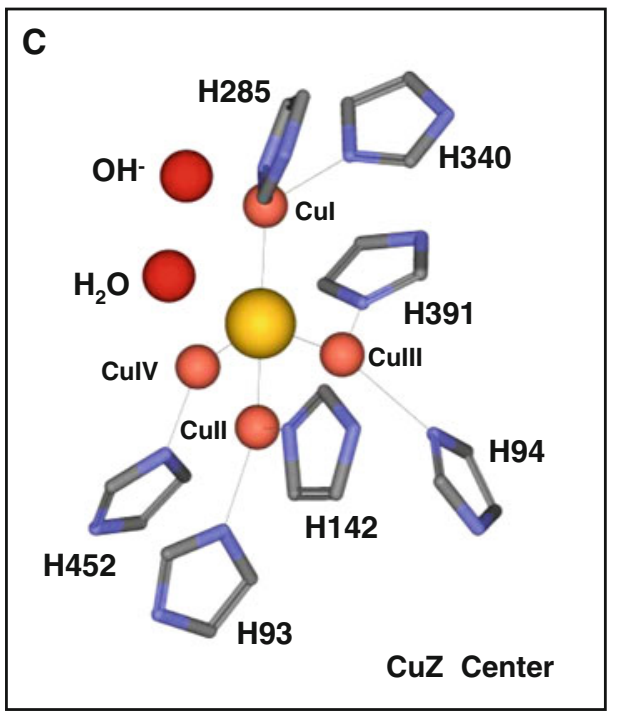

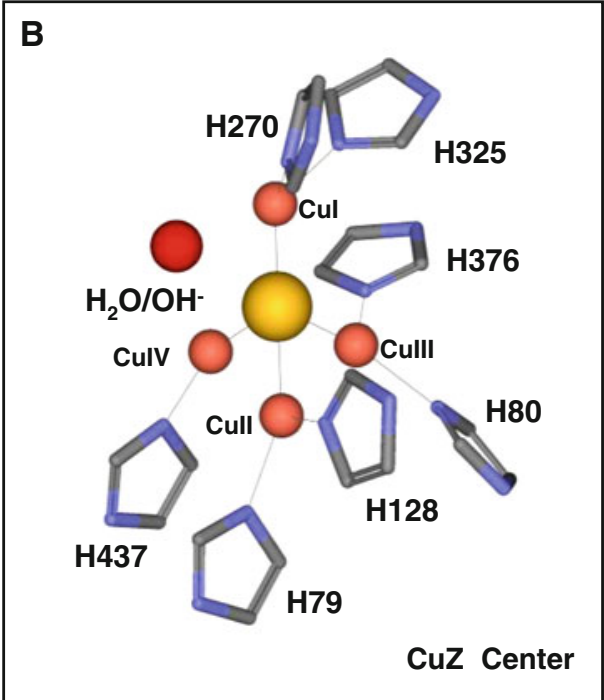

Paracoccus denitrificans

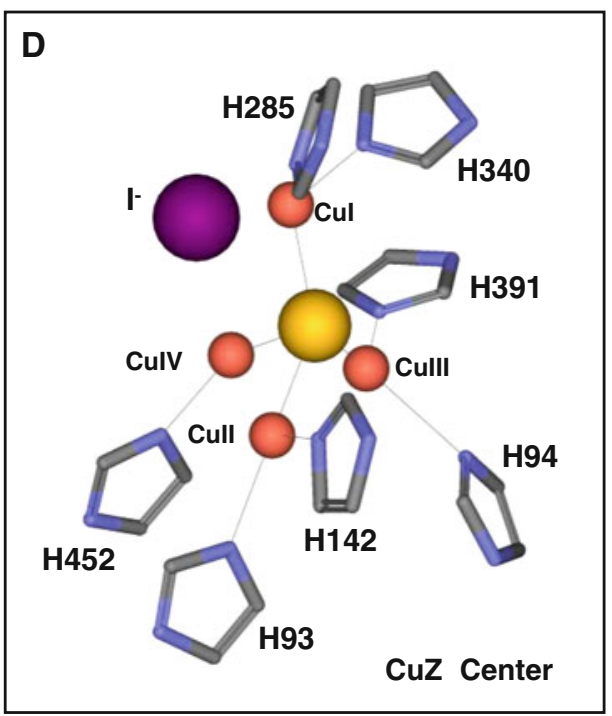

also determined in the presence of an inhibitor, iodide ion, which was shown to bind to the $\mathrm{CuZ}$ center in the $\mathrm{Cu}_{\mathrm{I}}-\mathrm{Cu}_{\mathrm{IV}}$ edge [62] (Fig. 2, Panel D).

Since the edge between $\mathrm{Cu}_{\mathrm{I}}-\mathrm{Cu}_{\mathrm{IV}}$ of the $\mathrm{CuZ}$ center could accommodate water and/or hydroxyl groups and also an inhibitor, this site was proposed to be the substrate binding site. Density functional theory (DFT) calculations suggested the binding of a bent $\mathrm{N}_{2} \mathrm{O}$ molecule between $\mathrm{Cu}_{\mathrm{I}}$ and $\mathrm{Cu}_{\mathrm{IV}}$ (vide infra) [63]. In this model the oxygen and the terminal nitrogen are in positions equivalent to those of the two oxygen atoms identified in the X-ray structure of the Achromobacter cycloclastes $\mathrm{CuZ}$ center (Fig. 3). After a catalytic cycle and upon release of $\mathrm{N}_{2}$, the remaining oxygen can stay bound in a bridging position similar to that found for the iodide in the inhibitor- $\mathrm{CuZ}$ center bound structure (Fig. 2, Panel D).

The catalytic $\mathrm{CuZ}$ center is located in the N-terminal domain, which adopts a seven-blade $\beta$-propeller fold, whereas the electron transfer center, $\mathrm{CuA}$, is located in the C-terminal cupredoxin domain. Moreover, the threedimensional structure of $\mathrm{N}_{2} \mathrm{OR}$ also revealed the functional homodimeric conformation of this enzyme. Indeed, although the distance, within the same monomer, between the electron transferring center $(\mathrm{CuA}$ center) and the catalytic center ( $\mathrm{CuZ}$ center) is around $40 \AA$, the $\mathrm{CuA}-\mathrm{CuZ}$ distance within the dimer is approximately $10 \AA$ (Fig. 1, Panel B), which is considered suitable for efficient electron transfer [64]. 


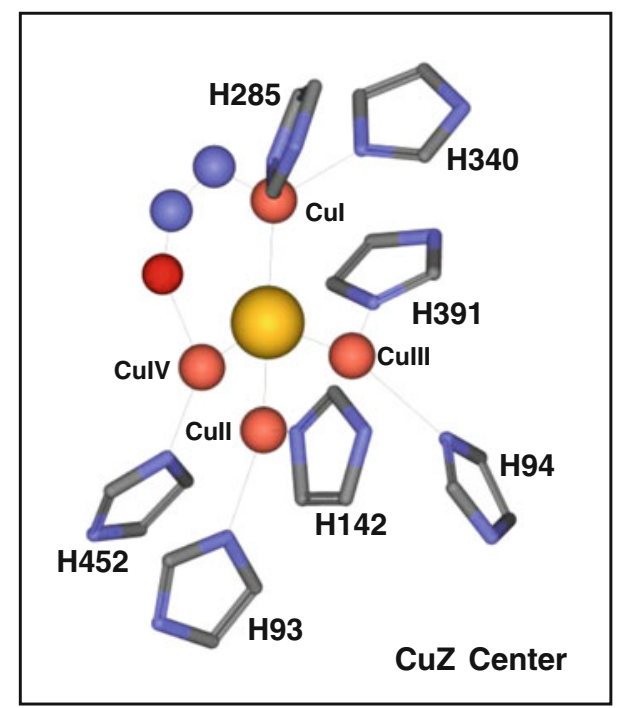

Fig. 3 Representation of the $\mathrm{CuZ}$ center with the substrate bound in a $\mu-1,3-\mathrm{N}_{2} \mathrm{O}$ bridging mode. The figure was created with DSViewer Pro 5.0 (Accelrys) using 2IWF and based on the model proposed in [63], which was obtained by density functional theory calculations

\section{Spectroscopy of the different redox states of the $\mathrm{CuZ}$ center}

To understand the electronic properties of the metal centers in $\mathrm{N}_{2} \mathrm{OR}$, a large amount of spectroscopic data has collected in recent years, interpretation of which was revisited after the determination of the first crystal structure.

The visible spectrum of the as-isolated $\mathrm{N}_{2} \mathrm{OR}$, purified in an anaerobic chamber for the exclusion of oxygen, has overlapping absorption bands of the two copper centers, $\mathrm{CuA}$ and $\mathrm{CuZ}$ centers, which hinders the deconvolution of their spectroscopic features. In this form of the enzyme (Table 1, form A), the CuA center has absorption bands at 480, 550, and $780 \mathrm{~nm}$ and the $\mathrm{CuZ}$ center contributes with an absorption at $540 \mathrm{~nm}$ [56].
The spectroscopic and electronic properties of the $\mathrm{CuA}$ center have been extensively investigated, not only in $\mathrm{N}_{2} \mathrm{OR}$, but also in COX [47, 65, 66].

Most of the initial spectroscopic characterization of the $\mathrm{CuZ}$ center was performed using the dithionite-reduced form of $\mathrm{N}_{2} \mathrm{OR}$ isolated either with exclusion or in the presence of oxygen, in which the $\mathrm{CuA}$ center is reduced and is in the spectroscopic silent state $\left(\mathrm{Cu}^{+}-\mathrm{Cu}^{+}\right)(S=0)$. In those dithionite-reduced $\mathrm{N}_{2} \mathrm{OR}$ forms, the $\mathrm{CuZ}$ center is in the $\mathrm{CuZ}$ state (Table 1, form $\mathrm{C}$ ) and the $\mathrm{CuZ}^{*}$ state (Table 1, form-E), respectively. Dithionite-reduced CuZ and $\mathrm{CuZ}^{*}$ are characterized by a broad absorption band with a maximum at around $640 \mathrm{~nm}$ and an EPR signal, with $g$ values at 2.15-2.18 and 2.04-2.06 and four-line hyperfine splitting $[28,59,67]$ (Table 2).

However, in the early purifications from Pseudomonas stutzeri, it became clear that the enzyme can be isolated with the $\mathrm{CuZ}$ center in different redox states depending on the procedure used during the purification. Indeed, the $\mathrm{N}_{2} \mathrm{OR}$ purified under the exclusion of oxygen from Pseudomonas stutzeri, Alcaligenes xylosoxidans, Paracoccus denitrificans, and Paracoccus pantotrophus [28, 32, 40, 68] exhibits an intense absorption at $540 \mathrm{~nm}$ and a less intense band around $800 \mathrm{~nm}$. This form of $\mathrm{N}_{2} \mathrm{OR}$, which was defined as "purple" (Table 1, form A), has the CuA center in the oxidized state, since the EPR spectrum exhibits the typical seven-line hyperfine pattern in the $g_{\|}$region, and the $\mathrm{CuZ}$ center is also in the oxidized state that is considered to be $\left[2 \mathrm{Cu}^{2+}-2 \mathrm{Cu}^{+}\right]$. On the other hand, $\mathrm{N}_{2} \mathrm{OR}$ isolated in the presence of oxygen from these bacterial sources is in a different form, named "pink" (Table 1, form D). The pink $\mathrm{N}_{2} \mathrm{OR}$ is characterized by a different visible spectrum, with absorption maxima at 480, 550, and $640 \mathrm{~nm}$ and a shoulder at $780 \mathrm{~nm}$. This form also has the CuA center in the oxidized state, but the $\mathrm{CuZ}$ center is in an oxidation state $\left(\left[1 \mathrm{Cu}^{2+}-3 \mathrm{Cu}^{+}\right]\right)$different from that found in the purple form and was named $\mathrm{CuZ}^{*}$. Therefore, since the $\mathrm{CuA}$

Table 1 Different redox forms of nitrous oxide reductase $\left(\mathrm{N}_{2} \mathrm{OR}\right)$

\begin{tabular}{|c|c|c|c|c|}
\hline & $\mathrm{CuA}$ & $\mathrm{CuZ}$ & $\mathrm{CuZ}^{*}$ & \\
\hline \multicolumn{5}{|c|}{ Exclusion of dioxygen } \\
\hline A & {$\left[\mathrm{Cu}^{1.5+}-\mathrm{Cu}^{1.5+}\right]^{3+}$} & {$\left[2 \mathrm{Cu}^{2+}-2 \mathrm{Cu}^{+} \mathrm{S}\right]^{4-}$} & & Purple form as isolated \\
\hline B & {$\left[\mathrm{Cu}^{+}-\mathrm{Cu}^{+}\right]^{2+}$} & {$\left[2 \mathrm{Cu}^{2+}-2 \mathrm{Cu}^{+} \mathrm{S}\right]^{4-}$} & & "Semireduced" ascorbate reduced \\
\hline $\mathrm{C}$ & {$\left[\mathrm{Cu}^{+}-\mathrm{Cu}^{+}\right]^{2+}$} & {$\left[1 \mathrm{Cu}^{2+}-3 \mathrm{Cu}^{+} \mathrm{S}\right]^{3-}$} & & Dithionite-reduced \\
\hline \multicolumn{5}{|c|}{ Presence of oxygen } \\
\hline $\mathrm{D}$ & {$\left[\mathrm{Cu}^{1.5+}-\mathrm{Cu}^{1.5+}\right]^{3+}$} & & {$\left[1 \mathrm{Cu}^{2+}-3 \mathrm{Cu}^{+} \mathrm{S}\right]^{3+}$} & Pink form as isolated \\
\hline E & {$\left[\mathrm{Cu}^{+}-\mathrm{Cu}^{+}\right]^{2+}$} & & {$\left[1 \mathrm{Cu}^{2+}-3 \mathrm{Cu}^{+} \mathrm{S}\right]^{3+}$} & Blue form ${ }^{\mathrm{a}}$ dithionite reduced \\
\hline $\mathrm{F}$ & {$\left[\mathrm{Cu}^{+}-\mathrm{Cu}^{+}\right]^{2+}$} & & {$\left[4 \mathrm{Cu}^{+} \mathrm{S}\right]^{2+}$} & Fully reduced activated form \\
\hline
\end{tabular}

"In the "blue form" of $\mathrm{N}_{2} \mathrm{OR}$, the CuZ center is found mainly in the CuZ* state, which has also been named "resting CuZ." This form is different from the one present in form $\mathrm{C}$, although they have the same redox state. The CuZ center in form C has slightly different absorption bands and a slightly different EPR spectrum from the one in forms D and $\mathrm{E}$, and the CuZ center in form $\mathrm{C}$ is redox-active, whereas in forms $\mathrm{D}$ and $\mathrm{E}$ it is redox-inactive $[67,68]$ 
Table 2 The different oxidation states of the CuZ center and their catalytic and spectroscopic properties

\begin{tabular}{|c|c|c|c|c|c|}
\hline Oxidation states & Designation & $\begin{array}{l}\text { Catalytic } \\
\text { properties }\end{array}$ & $\begin{array}{l}\text { Visible } \\
\text { absorption (nm) }\end{array}$ & EPR & References \\
\hline$\left[4 \mathrm{Cu}^{2+} \mathrm{S}\right]^{6+}$ & Not yet observed & - & - & - & \\
\hline$\left[3 \mathrm{Cu}^{2+}-1 \mathrm{Cu}^{+} \mathrm{S}\right]^{5+}$ & Not yet observed & - & - & - & \\
\hline$\left[2 \mathrm{Cu}^{2+}-2 \mathrm{Cu}^{+} \mathrm{S}\right]^{4+}$ & $\begin{array}{l}\mathrm{CuZ} \text {, found } \\
\text { in purple } \mathrm{N}_{2} \mathrm{OR}\end{array}$ & $\begin{array}{l}\text { Redox active }\left(E^{\prime \circ}=60 \mathrm{mV}\right) \\
\text { not catalytically active }\end{array}$ & 540 & EPR silent & {$[56,68]$} \\
\hline \multirow[t]{3}{*}[1\mathrm{Cu}^{2+}-3\mathrm{Cu}^{+}\mathrm{S}]{$^{3+}$} & $\mathrm{CuZ}$ & Not active & 640 & $g_{\|}=2.150 ; g_{\perp}=2.035$ & {$[67,68]$} \\
\hline & $\mathrm{CuZ} *$ & Not active & 640 & $g_{\|}=2.160 ; g_{\perp}=2.040$ & {$[59,69]$} \\
\hline & $\mathrm{CuZ}^{\circ}$ & Highly active & 680 & $g_{\|}=2.160 ; g_{\perp}=2.037$ & {$[90]$} \\
\hline$\left[4 \mathrm{Cu}^{+} \mathrm{S}\right]^{2+}$ & Fully reduced & Highly active & None & EPR silent & {$[63,77]$} \\
\hline
\end{tabular}

center exhibits absorption maxima at 480, 550, and $780 \mathrm{~nm}$, the $\mathrm{CuZ}$ center in the form of $\mathrm{CuZ}^{*}$ is characterized by an absorption band at $640 \mathrm{~nm}$.

The reduction of the purple $\mathrm{N}_{2} \mathrm{OR}$ (Table 1 , form $\mathrm{A}$ ) by sodium dithionite proceeds in two kinetic steps: a fast phase in which the absorbance at $540 \mathrm{~nm}$ decreases and the shoulder at $800 \mathrm{~nm}$ disappears almost within seconds, owing to the reduction of the $\mathrm{CuA}$ center (Table 1, form B), and a slower phase, in which a "blue" form is generated in the course of minutes (Table 1, form $\mathrm{C}$ ), characterized by a decrease and almost disappearance of the 550-nm absorption band and an increase in the 640-nm absorption band [21]. Therefore, the enzyme when purified under the exclusion of oxygen can be in an "as-isolated" (Table 1, form A), a "semireduced" (Table 1, form B), and a "dithionite-reduced" (Table 1, form C) form.

The EPR spectrum of the "as-isolated," purple form (Table 1, form A) exhibits a well-defined seven-line hyperfine splitting, whereas that of the dithionite-reduced form (Table 1, form $\mathrm{C}$ ) has a broad and poorly resolved four-line hyperfine splitting signal [43]. However, the "semireduced" form (Table 1, form B), obtained by reducing the "purple" form with sodium ascorbate, shows an extremely weak EPR signal and must be considered EPR-silent, but still has an absorption band at $540 \mathrm{~nm}$. MCD data confirmed that the "semireduced" form (Table 1, form B) is not a ferromagnetically coupled $(S=1)$ center but is an antiferromagnetically coupled center $(S=0)$ [56].

Farrar et al. [43] suggested the presence of two distinct forms of the $\mathrm{CuZ}$ center, named $\mathrm{CuZ}$ and $\mathrm{CuZ}^{*}$. In particular, the catalytic center can exist in a redox-active form, $\mathrm{CuZ}$, and in a redox-inactive form, $\mathrm{CuZ}^{*}$, in which the $\mathrm{CuZ}$ center is $\left[2 \mathrm{Cu}^{2+}-2 \mathrm{Cu}^{+}\right]$and $\left[1 \mathrm{Cu}^{2+}-3 \mathrm{Cu}^{+}\right]$, respectively. It was also noticed that the amount of $\mathrm{CuZ}^{*}$ species was dependent on the $\mathrm{N}_{2} \mathrm{OR}$ isolation procedure. It was shown that the proportion of $\mathrm{CuZ}^{*}$ is minimal in Pseudomonas stutzeri $\mathrm{N}_{2} \mathrm{OR}$ isolated under the exclusion of oxygen [43]. In fact, the Paracoccus pantotrophus $\mathrm{N}_{2} \mathrm{OR}$ purified under the exclusion of oxygen has a $\mathrm{CuZ}^{*}$ to total $\mathrm{CuZ}$ ratio of 0.29 , whereas in the preparation in the presence of oxygen, this ratio is 0.66 [68].

In summary, the spectroscopic, electronic, and structural characterization of the $\mathrm{CuZ}$ center in the purple form $\left[2 \mathrm{Cu}^{2+}-2 \mathrm{Cu}^{+}\right]$is still far from complete, owing to the interference and overlapping of the $\mathrm{CuA}$ center spectroscopic features and thus more spectroscopic and structural data for this form are required.

On the other hand, the "blue" form of $\mathrm{N}_{2} \mathrm{OR}$, which has the $\mathrm{CuZ}$ center mainly as $\mathrm{CuZ} *$ (Table 1 , form $\mathrm{E}$ ), has been extensively characterized in recent years by Solomon and coworkers. MCD spectroscopy showed that the paramagnetic state of the Pseudomonas nautica "blue" $\mathrm{N}_{2} \mathrm{OR}$ (which has the $\mathrm{CuZ}$ center mainly as $\mathrm{CuZ}^{*}$ ) has an $S=1 / 2$ spin state [69]. Furthermore, Cu K-edge X-ray absorption spectroscopy was used to distinguish between the two possible configurations for the tetranuclear copper center, $\left[1 \mathrm{Cu}^{2+}-3 \mathrm{Cu}^{+}\right]$or $\left[3 \mathrm{Cu}^{2+}-1 \mathrm{Cu}^{+}\right]$, with the experimental data being better fitted considering that the oxidation state of the $\mathrm{CuZ}$ center is $\left[1 \mathrm{Cu}^{2+}-3 \mathrm{Cu}^{+}\right]$. In addition, the unpaired electron spin distribution of the $\mathrm{CuZ}$ center in the dithionitereduced state of this enzyme was determined by Q-band and $\mathrm{X}$-band EPR spectroscopic studies in combination with DFT calculations. It revealed that the spin density is mainly distributed between $\mathrm{Cu}_{\mathrm{I}}(42 \%)$ and $\mathrm{Cu}_{\mathrm{II}}(16 \%)$, with a small contribution from the other two copper ions $\left(\mathrm{Cu}_{\mathrm{III}} 8 \%\right.$ and $\mathrm{Cu}_{\mathrm{IV}} 3 \%$ ) and a significant contribution from the bridging sulfide (14\%) [69]. A similar EPR-DFT calculation study was performed on the two dithionite-reduced forms of the $\mathrm{CuZ}$ center of Paracoccus pantotrophus $\mathrm{N}_{2} \mathrm{OR}, \mathrm{CuZ}$ (Table 1, form C) and CuZ* (Table 1, form E). The results obtained are similar to those obtained for Pseudomonas nautica $\mathrm{N}_{2} \mathrm{OR}$ but with the spin density being more widely distributed over the $\mathrm{CuZ}$ center $\left(\mathrm{Cu}_{\mathrm{I}} 20.1 \%, \mathrm{Cu}_{\mathrm{II}} 9.5 \%, \mathrm{Cu}_{\text {III }}\right.$ $4.8 \%, \mathrm{Cu}_{\mathrm{IV}} 9.2 \%$, and $\mathrm{S} 17.9 \%$ ) [67].

Other spectroscopic methods, such as resonance Raman and low-temperature absorption spectroscopies, coupled with DFT calculations revealed that the spectral features of 
the dithionite-reduced $\mathrm{CuZ}$ center, $\mathrm{CuZ}^{*}$ (Table 1, form $\mathrm{E}$ ), are dominated by the $\mathrm{S} \rightarrow \mathrm{Cu}_{\mathrm{I}}$ charge-transfer transition $[59,70]$. In particular, the three main frequency lines in the resonance Raman spectra, at 366, 386 and $415 \mathrm{~cm}^{-1}$, are associated with $\mathrm{Cu}-\mathrm{S}$ vibrations and contribute to the broad charge-transfer absorption band at approximately $640 \mathrm{~nm}$ (approximately 15,650 $\mathrm{cm}^{-1}$ ). These three transitions are associated with excitations from the three $p$ orbitals of the $\mu 4$-bridging sulfide.

\section{Activation of the $\mathrm{CuZ}$ center}

The reduction of $\mathrm{N}_{2} \mathrm{O}$ is a thermodynamically favorable reaction with $\Delta G \approx-104.6 \mathrm{~kJ} \mathrm{~mol}^{-1}$ but its thermodecomposition is kinetically inert owing to the activation barrier of approximately $250 \mathrm{~kJ} \mathrm{~mol}^{-1}$, which is consistent with a spin-forbidden process $[21,71]$. Although $\mathrm{N}_{2} \mathrm{O}$ is a weak ligand for metals, because it is a weak $\sigma$-donor and weak $\pi$-acceptor molecule, several complexes of transition metals are able to bind and activate $\mathrm{N}_{2} \mathrm{O}$ [72, 73]. However, the $\mathrm{M}-\mathrm{N}_{2} \mathrm{O}$ complexes reported so far are transient species and no $\mathrm{X}$-ray structure is available, since that intermediate is rapidly converted to nitrogen and to the corresponding metal-oxidized species. These studies are consistent with a reaction mechanism involving the scission of the $\mathrm{NN}-\mathrm{O}$ bond [72].

In biological systems, it was known even before the isolation and purification of $\mathrm{N}_{2} \mathrm{OR}$ that denitrifying bacteria have the ability to reduce $\mathrm{N}_{2} \mathrm{O}$ to $\mathrm{N}_{2}$. Several assays were developed to test the enzyme activity, such as gas chromatography methods [74] and the Clark-type electrode [75], but the most used assay was the one developed by Kristjansson and Hollocher [76], in which the oxidation of methylviologen cation radical or benzylviologen cation radical was followed upon addition of $\mathrm{N}_{2} \mathrm{O}$.

One of the important aspects for the understanding of the catalytic cycle and activity of $\mathrm{N}_{2} \mathrm{OR}$ is the identification and characterization of active intermediates that are able to bind and reduce $\mathrm{N}_{2} \mathrm{O}$. As already mentioned, the $\mathrm{CuZ}$ center of the dithionite-reduced $\mathrm{N}_{2} \mathrm{OR}$ (CuZ*, Table 1 , form E) cannot be further reduced or oxidized (using dithionite or ferricyanide, respectively), and is thus redoxinactive. On the other hand, the activity assay with reduced methylviologen suggested that a negative potential and a long incubation time were necessary to reduce the nonactive $\mathrm{CuZ}^{*}$ center to the fully reduced active $\mathrm{CuZ}$ state (Table 1, form F).

Indeed, it was later shown that a prolonged incubation with excess reduced methylviologen fully reduces the $\mathrm{CuZ}^{*}$ center $\left[1 \mathrm{Cu}^{2+}-3 \mathrm{Cu}^{+}\right]$to the super-reduced form $\left[4 \mathrm{Cu}^{+}\right]$. The $\mathrm{CuZ}$ center in the fully reduced state is characterized by being spectroscopically silent, as no EPR signal is detected and no contributions are observed in the visible region. Parallel activity assays demonstrated that the enzyme activity increased with increasing incubation time and that the increase in activity was directly correlated with the decrease in intensity of CuZ* EPR and visible features $[63,77]$.

Therefore, these studies demonstrate that the electronrich site of the fully reduced $\mathrm{CuZ}$ center is required to bind and catalyze the two-electron reduction of $\mathrm{N}_{2} \mathrm{O}$ to $\mathrm{N}_{2}$.

As mentioned before, $\mathrm{N}_{2} \mathrm{OR}$ from Pseudomonas stutzeri, Paracoccus pantotrophus, and Paracoccus denitrificans can be isolated with the $\mathrm{CuZ}$ center in a redox-active form (Table 1, form A) [56, 68, 78]. The CuZ center in this form is proposed to be in the $\left[2 \mathrm{Cu}^{2+}-2 \mathrm{Cu}^{+}\right]$oxidation state, which can be reduced by a single electron and has a midpoint reduction of $E^{\prime \circ}=60 \mathrm{mV}$ [68], corresponding to the couple $\left[2 \mathrm{Cu}^{2+}-2 \mathrm{Cu}^{+}\right]-\left[1 \mathrm{Cu}^{2+}-3 \mathrm{Cu}^{+}\right]$. It is important to point out that this $\left[1 \mathrm{Cu}^{2+}-3 \mathrm{Cu}^{+}\right] \mathrm{CuZ}$ state is probably not in the same configuration as the $\left[1 \mathrm{Cu}^{2+}-3 \mathrm{Cu}^{+}\right]$state of $\mathrm{CuZ}^{*}$, as the latter is redox-inactive.

Although the $\left[2 \mathrm{Cu}^{2+}-2 \mathrm{Cu}^{+}\right] \mathrm{CuZ}$ form is redox-active, $\mathrm{N}_{2} \mathrm{OR}$ with the $\mathrm{CuZ}$ center in this state (Table 1, form A) has very low catalytic activity, similar to that determined for the enzyme with the $\mathrm{CuZ}$ center in the $\mathrm{CuZ}^{*}$ state [68]. Indeed, it was shown that the activity of the "purple" Achromobacter cycloclastes $\mathrm{N}_{2} \mathrm{OR}$ increased from 8 to $125 \mathrm{U} \mathrm{mg}^{-1}$ after incubation with methylviologen, demonstrating that this form of the enzyme also requires activation to fully reduce the $\mathrm{CuZ}$ center and thus attain maximum activity [77].

In conclusion, $\mathrm{N}_{2} \mathrm{OR}$ isolated either under the exclusion (form $\mathrm{A} \rightarrow$ form $\mathrm{F}$ ) or in the presence of oxygen (form $\mathrm{D} \rightarrow$ form $\mathrm{F}$ ) always requires an activation process to fully reduce the $\mathrm{CuZ}$ center, and it is only the fully reduced form of the enzyme (Table 1, form $\mathrm{F}$ ) that has the maximum specific activity.

The activation mechanism of $\mathrm{N}_{2} \mathrm{OR}$ is still not completely understood, i.e., whether there are only changes in the redox state of the CuZ center or additional modifications occur in the coordination sphere of the copper ions of the $\mathrm{CuZ}$ center. Recently, it was demonstrated that there is a protonation step associated with this activation process, with a $\mathrm{p} K_{\mathrm{a}}$ of 9.2 , which was assigned to a lysine that is in close proximity to the CuZ center (Lys-397 in Pseudomonas nautica). It was proposed that the protonation of this lysine facilitates the reduction of the $\mathrm{CuZ}$ center from the CuZ* form (Table 1, form E) to the fully reduced form (Table 1, form F) [79].

\section{Catalytic properties of $\mathrm{CuZ}$ and reaction intermediates}

To clarify the catalytic mechanism of $\mathrm{N}_{2} \mathrm{O}$ reduction, several kinetic studies were performed and the kinetic 
parameters were determined in assays that used either physiological (type 1 copper protein or $c$-type cytochrome) or artificial (e.g., methylviologen or benzylviologen) electron donors. In the assays that used methylviologen or benzylviologen as electron donors, $K_{\mathrm{m}}$ for the substrate was determined to be in the low micromolar range, whereas $V_{\max }$ varied with the bacterial source of the enzyme (Table 3 ).

It is important to point out that a comparison between earlier values is not possible because in the earlier assays the enzyme was not activated, i.e., the $\mathrm{CuZ}$ center was not fully reduced and thus the maximum activity attained would be strongly dependent on the time of incubation (time required for enzyme activation) [63, 77], which was not always stated. Thus, $\mathrm{N}_{2} \mathrm{OR}$ in those assays has to be viewed as being in different intermediate states of activation.

To avoid this problem, the activity assay was recently modified to separate the activation process from the catalytic cycle [80]. In these assays, $\mathrm{N}_{2} \mathrm{OR}$ is activated with reduced methylviologen, which is removed by a desalting chromatographic step, so that the addition of activated $\mathrm{N}_{2} \mathrm{OR}$ initiates the enzymatic assay.

Small electron donor proteins, as $c$-type cytochromes, either physiological or nonphysiological (mitochondrial cytochrome $c$ ), have been used as electron donors to $\mathrm{N}_{2} \mathrm{OR}$ in in vitro assays [81]. In the case of $\mathrm{N}_{2} \mathrm{OR}$ isolated from Rhodobacter capsulatus, Rhodobacter sphaeroides f. sp. denitrificans, and Paracoccus pantotrophus [37, 82, 83], the physiological donor is a periplasmic $c$-type cytochrome, but Paracoccus pantotrophus $\mathrm{N}_{2} \mathrm{OR}$ can also accept electrons from a periplasmic type 1 copper protein, pseudoazurin [37], and from the mitochondrial horse heart cytochrome $c$ [81]. Bovine heart cytochrome $c$ is able to reduce Achromobacter cycloclastes $\mathrm{N}_{2} \mathrm{OR}$ [84], but its physiological electron donor is pseudoazurin [85].

Wolinella succinogenes $\mathrm{N}_{2} \mathrm{OR}$ is proposed to have a peculiar structure, with an extra $\mathrm{C}$-terminal domain containing a $c$-type heme $[33,86]$. A periplasmic $c$-type cytochrome isolated from the same organism was shown to be the putative electron donor to this enzyme [87].

In the case of Pseudomonas nautica $\mathrm{N}_{2} \mathrm{OR}$, a kinetic analysis comparing cytochrome $c$-552, the established

Table 3 Summary of the kinetic properties of the different $\mathrm{N}_{2} \mathrm{ORs}$

\begin{tabular}{|c|c|c|c|c|c|c|c|}
\hline $\mathrm{N}_{2} \mathrm{OR}$ & $\begin{array}{l}\text { Enzyme } \\
\text { form }\end{array}$ & $\begin{array}{l}\text { Electron } \\
\text { donor }\end{array}$ & $\begin{array}{l}K_{\mathrm{m}} \\
\text { for } \\
\mathrm{ED} \\
(\mu \mathrm{M})\end{array}$ & $\begin{array}{l}K_{\mathrm{m}} \\
\text { for } \\
\mathrm{N}_{2} \mathrm{O}\end{array}$ & $\begin{array}{l}V_{\max } \\
\left(\mathrm{U} \mathrm{mg}^{-1}\right)\end{array}$ & $\begin{array}{l}\mathrm{p} K_{\mathrm{a}} / \text { optimal } \\
\mathrm{pH}\end{array}$ & Reference \\
\hline \multirow[t]{2}{*}{ Pseudomonas aeruginosa } & As-prepared & BV & & & 0.5 & & {$[36]$} \\
\hline & Activated (incubated) & BV & 4 & 2 & 27 & & \\
\hline \multirow[t]{2}{*}{ Pseudomonas stutzeri } & Purple (“anaerobic") & BV & & & $\begin{array}{l}4(60 \text { at } \mathrm{pH} \\
9.8)\end{array}$ & $\begin{array}{l}\text { Optimal pH } \\
9-10\end{array}$ & {$[28]$} \\
\hline & Pink (“aerobic") & BV & & & 2 & & \\
\hline $\begin{array}{l}\text { Pseudomonas } \\
\text { denitrificans }\end{array}$ & Purple ("anaerobic") & MV & & 7 & 122 & & {$[32]$} \\
\hline \multirow{3}{*}{$\begin{array}{c}\text { Achromobacter } \\
\text { cycloclastes }\end{array}$} & Anaerobic (pink) & MV & & & 86 & & {$[35]$} \\
\hline & $\begin{array}{l}\text { Anaerobic (blue) not } \\
\text { incubated }\end{array}$ & MV & & & 7 & & {$[84]$} \\
\hline & Anaerobic (blue) incubated & MV & & 25 & 124 & & \\
\hline Alcaligenes xyloxidans & As-isolated (purple) & MV & & & 6 & & {$[40]$} \\
\hline \multirow[t]{3}{*}{ Paracoccus pantotropus } & Anaerobic & MV & & & 3 & & {$[68]$} \\
\hline & Aerobic & MV & & & 9 & & \\
\hline & & $\begin{array}{l}\text { Horse heart cytochrome } \\
\qquad c\end{array}$ & 6 & & 0.03 & & [37] \\
\hline Rhodobacter sphaeroides & Aerobic (pink) & BV & 26 & & 63 & Optimal pH 9.0 & [92] \\
\hline \multirow{2}{*}{$\begin{array}{l}\text { Hyphomicrobium } \\
\text { denitrificans }\end{array}$} & A (violet) & BV & & & 45 & Optimal pH 8.8 & {$[42]$} \\
\hline & B (blue) & BV & & & 29 & & \\
\hline \multirow[t]{2}{*}{ Pseudomonas nautica } & Aerobic (mixed) & MV & 12 & 14 & 160 & $\mathrm{p} K_{\mathrm{a}} 6.6$ & {$[80]$} \\
\hline & & Cytochrome $c-552$ & 50 & - & 1.8 & $\mathrm{p} K_{\mathrm{a}} 8.3$ & \\
\hline Wolinella succinogenes & $\begin{array}{l}\text { Additional cytochrome } \\
c \text { domain }\end{array}$ & BV & 4 & 8 & 160 & & {$[33]$} \\
\hline
\end{tabular}

$E D$ electron donor, $M V$ methylviologen, $B V$ benzylviologen 
physiological electron donor, and methylviologen, the reductive agent that is required to activate this enzyme, points out that this small molecule is a more efficient electron donor [80]. In particular, methylviologen shows a higher turnover number than does cytochrome $c$-552 (300 and $4 \mathrm{~s}^{-1}$, respectively). Moreover, reduced cytochrome $c-552$ is able to donate electrons to the $\mathrm{CuA}$ center but it is not able to fully reduce the CuZ center when it is in the $\left[1 \mathrm{Cu}^{2+}-3 \mathrm{Cu}^{+}\right] \mathrm{CuZ}^{*}$ state, confirming that this state is inert and not part of the catalytic cycle.

The different mechanisms and modes of interaction of these two electron donors were also verified by the $\mathrm{pH}$ and electron donor concentration dependencies. In fact, when cytochrome $c-552$ is the electron donor, the electron transfer reaction is the rate-limiting step, whereas the reduction of $\mathrm{N}_{2} \mathrm{O}$ is slower in the case of methylviologen as the electron donor. Another difference was observed in the affinity, which is higher for methylviologen, with $K_{\mathrm{m}}$ of $12 \mu \mathrm{M}$, than for cytochrome $c-552$, with $K_{\mathrm{m}}$ of $50 \mu \mathrm{M}$. The other difference was found in the $\mathrm{pH}$ dependence of the catalytic activity, which is higher at basic $\mathrm{pH}$ values for methylviologen, whereas for cytochrome $c-552$ it is higher at more acidic values. The different reactivity is proposed to be correlated to a different type of interaction of methylviologen toward the enzyme, in particular owing to a direct reduction of the $\mathrm{CuZ}$ center, overpassing the internal electron flow between the $\mathrm{CuA}$ and $\mathrm{CuZ}$ centers of $\mathrm{N}_{2} \mathrm{OR}$ [88].

A mechanism for $\mathrm{CuZ}$ center reduction was derived from this kinetic analysis, in which the maximum activity of the enzyme is reached when a water molecule bridges $\mathrm{Cu}_{\mathrm{I}}$ and $\mathrm{Cu}_{\mathrm{IV}}$. At $\mathrm{pH}$ above 9, the deprotonation of the ligand makes the reduction of the $\mathrm{CuZ}$ center by the cytochrome $c-552$ reduced $\mathrm{CuA}$ center more difficult and rate-limiting. On the other hand, methylviologen is a stronger reducing agent and can directly reduce the $\mathrm{CuZ}$ center without the need to deliver electrons through the $\mathrm{CuA}$ center, ensuring a fast reduction even at basic $\mathrm{pH}$ values. The optimum $\mathrm{pH}$ for several $\mathrm{N}_{2} \mathrm{ORs}$ was determined to be in the range from 8.0 to 9.5 when methylviologen was used as the electron donor $[28,37,42$, 80].

A computational approach has also been applied to provide further insights into the catalytic mechanism and the binding mode of the substrate, $\mathrm{N}_{2} \mathrm{O}$. For the lowestenergy conformation of the fully reduced state, the most favorable binding mode of the substrate is bridging $\mathrm{Cu}_{\mathrm{I}}$ and $\mathrm{Cu}_{\mathrm{IV}}$, in a $\mu-1,3$ coordination (Fig. 3) [63]. After binding, $\mathrm{N}_{2} \mathrm{O}$ is proposed to be in a bent conformation, which facilitates the coordination of $\mathrm{N}_{2} \mathrm{O}$, by shifting the $\pi^{*}$ orbital of $\mathrm{N}_{2} \mathrm{O}$ close to the fully occupied $d$ orbitals of the fully reduced $\mathrm{CuZ}$ center and turning the substrate into a good electron acceptor [63].
The back-bonding interaction between $\mathrm{Cu} d$ and $\mathrm{N}_{2} \mathrm{O}$ $\pi^{*}$ enables the elongation of the $\mathrm{N}-\mathrm{N}$ and $\mathrm{N}-\mathrm{O}$ bonds and increases the electron density of the oxygen atom, activating it for electrophilic attack by a proton. The transition state is stabilized by the charge transfer, which leads to a strong $\mathrm{Cu}_{\mathrm{IV}}-\mathrm{O}$ bond. The $d^{10}$ configuration of all the copper atoms in the fully reduced form facilitates the backbonding by maximizing the $\mathrm{CuZ} \rightarrow \mathrm{N}_{2} \mathrm{O}$ charge transfer. In addition, the protein structure presents the structural support for the $\mathrm{CuZ}$ center, providing the hydrogen-bonding and noncovalent interactions that lower the activation barrier of the $\mathrm{N}-\mathrm{O}$ bond cleavage [73].

A different mechanism for the binding mode of $\mathrm{N}_{2} \mathrm{O}$ has been proposed by Bar-Nahum et al. [89], based on a synthetic model of the $\mathrm{CuZ}$ center, a trinuclear mixed-valence copper-sulfur complex $\left[\mathrm{Cu}_{3} \mathrm{~S}_{2}\right]^{2+}$ supported by tertiary amine ligands. This was the first copper complex able to catalyze the reduction of nitrous oxide to dinitrogen at low temperature. The DFT calculations proposed that the substrate binds between two copper ions through a single oxygen atom. Although this model differs from the one of Solomon and coworkers, mentioned before, it is proposed to have similar activation energy [59].

In the absence of reducing agents, the reaction of the fully reduced $\mathrm{CuZ}$ center with the substrate, $\mathrm{N}_{2} \mathrm{O}$, enabled the identification of an intermediate in the turnover cycle of the enzyme. This intermediated was named $\mathrm{CuZ}^{\circ}$ and is characterized by an absorption band at $680 \mathrm{~nm}$ [90]. This intermediate form is different from $\mathrm{CuZ}^{*}$, which is characterized by an absorption band at $640 \mathrm{~nm}$, although the oxidation state of the $\mathrm{CuZ}$ center is proposed to be the same $\left[1 \mathrm{Cu}^{2+}-3 \mathrm{Cu}^{+}\right]$(Table 1). Interestingly, these experiments showed that in contrast to $\mathrm{CuZ}^{*}, \mathrm{CuZ}^{\circ}$ is fully active, but in the absence of reducing agents to complete the catalytic cycle it rearranges to $\mathrm{CuZ}^{*}$. This is a slow process $\left(k=0.3 \mathrm{~min}^{-1}\right)$ when compared with the turnover rate (on the per second timescale). Although, the catalytic center provides the two electrons for the $\mathrm{N}_{2} \mathrm{O}$ reduction, those studies showed that this is concomitant with the rapid one-electron transfer from the $\mathrm{CuA}$ center to the $\mathrm{CuZ}$ center, rendering the two-electron oxidized form of $\mathrm{CuZ}$ too short lived to be detected in those conditions.

The identification of $\mathrm{CuZ}^{\circ}$ as an intermediate in the catalytic cycle allowed the revision of both the activation mechanism and the turnover cycle of $\mathrm{N}_{2} \mathrm{OR}$. The proposed mechanism for the reductive activation, catalytic mechanism, and inactivation of the CuZ center is shown in Fig. 4.

\section{Future perspectives}

Since the discovery of the $\mathrm{CuZ}$ center, a tetranuclear copper center bridged by sulfur, several properties of this 
Fig. 4 The possible mechanism of reduction, catalysis, and inactivation of the catalytic center CuZ. Copper ions are colored blue in the II oxidation state or light blue in the I oxidation state. In the $\mathrm{CuZ}^{*}$ form, the $\mathrm{Cu}^{\mathrm{I}}(\mathrm{II})$ ion is represented as a blue square to indicate that this form is inactive. In either $\mathrm{CuZ}$ or $\mathrm{CuA}$ centers, the unpaired electrons are delocalized within the cluster through the sulfur(s) atom(s), represented as yellow spheres, which in the case of the $\mathrm{CuA}$ center are two thiolates, from two cysteine side chains, and in the $\mathrm{CuZ}$ center a sulfide

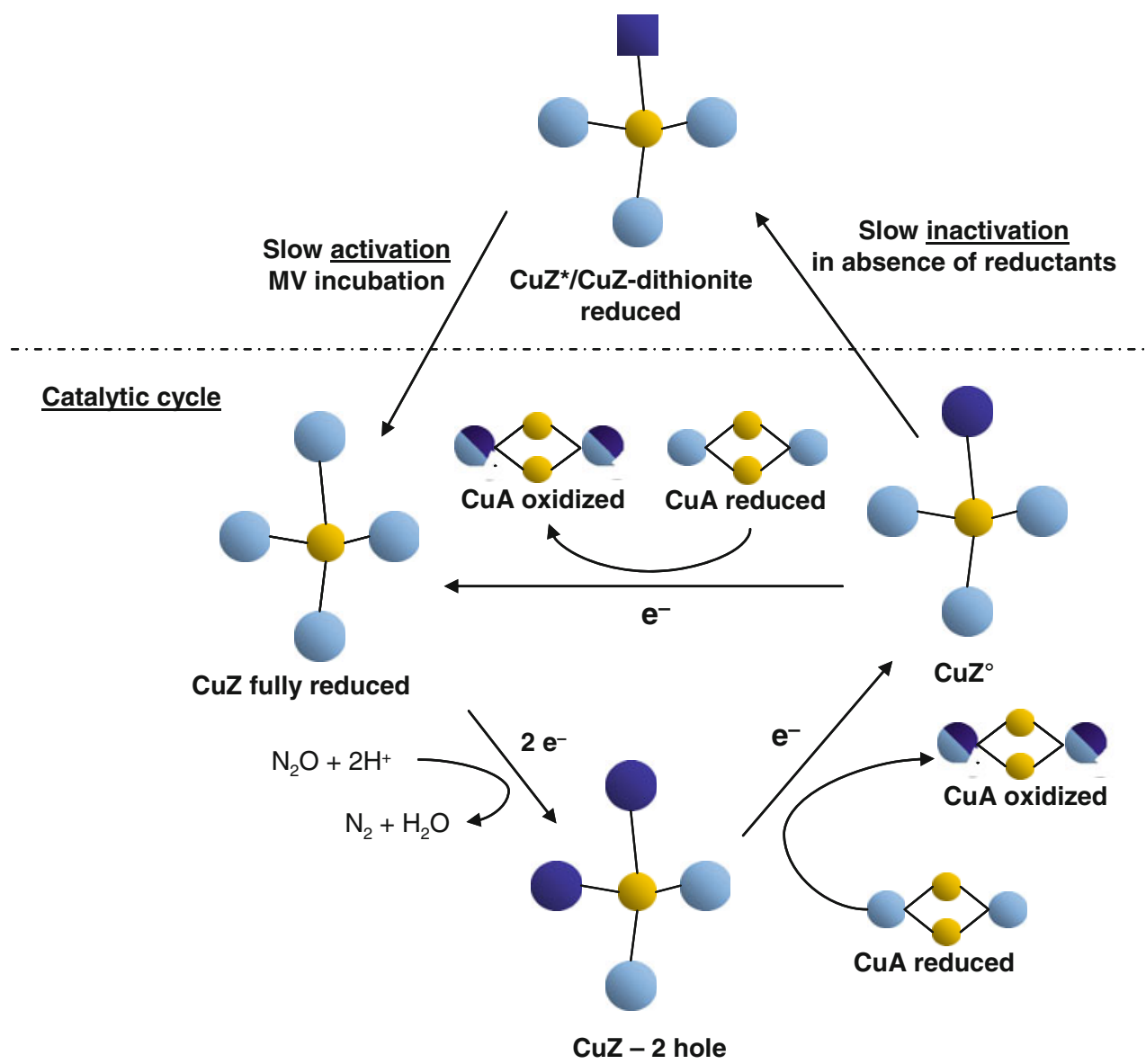

center have been elucidated, demonstrating the novelty of this bioinorganic cluster in terms of its structure and reactivity. However, the $\mathrm{CuZ}$ center still represents a challenge in biochemistry since many questions remain to be answered, such as aspects regarding the catalytic mechanism and the structure of the fully reduced (activated) $\mathrm{CuZ}$ center.

As mentioned, the "purple", "pink," and "blue" forms of $\mathrm{N}_{2} \mathrm{OR}$ have very low activity when compared with the enzyme in the fully reduced form or with the intermediate $\mathrm{CuZ}^{\circ}$. This suggests that a conformational change in the protein structure, in the cluster geometry, or in its coordination needs to occur to reach the optimal configuration for catalysis. Thus, structural data on $\mathrm{N}_{2} \mathrm{OR}$ with the $\mathrm{CuZ}$ center in different redox states (especially in the fully reduced) might also provide enlightenment as to why the enzyme is only fully active after a prolonged reduction.

The only intermediate of the $\mathrm{N}_{2} \mathrm{OR}$ catalytic cycle that has been observed is $\mathrm{CuZ}^{\circ}$, which has the $\mathrm{CuZ}$ center in the $\left[1 \mathrm{Cu}^{2+}-3 \mathrm{Cu}^{+}\right]$state. $\mathrm{CuZ}^{\circ}$ is highly active, with a turnover number similar to that of the fully reduced enzyme, which contrasts with the low activity of the blue or dithionitereduced $\mathrm{N}_{2} \mathrm{OR}$, which also has the $\mathrm{CuZ}$ center in the $\left[1 \mathrm{Cu}^{2+}-3 \mathrm{Cu}^{+}\right]$state. This difference might be explained after the elucidation of the electronic properties of $\mathrm{CuZ}{ }^{\circ}$ by spectroscopic techniques, such as MCD and resonance Raman spectroscopies. However, the first intermediate of the $\mathrm{CuZ}$ center after $\mathrm{N}_{2} \mathrm{O}$ reduction has been proposed to be a $\left[2 \mathrm{Cu}^{2+}-2 \mathrm{Cu}^{+}\right]$state. This intermediate has not yet been trapped under turnover conditions, probably because fast delivery of one electron from the $\mathrm{CuA}$ center makes this form very short lived. Therefore, stopped-flow kinetics and rapid-freeze quenching techniques will be required to trap and characterize this key intermediate in the turnover cycle.

Another question is the role of the sulfide bridging the four copper ions in the catalytic mechanism of $\mathrm{N}_{2} \mathrm{OR}$. Currently, the sulfide is proposed to be involved in the delocalization of the electronic spin density in the $\mathrm{CuZ}$ center. However, all the spectroscopic data were acquired on a nonactive resting state of the enzyme and it can be postulated that the sulfide has a critical role during the catalytic cycle of the enzyme to lower the activation energy. The involvement of the sulfur in the activation mechanism and catalytic mechanism still remains to be determined.

Experiments performed with the isolated enzyme are for obvious reasons considered important and irreplaceable. 
Nevertheless, the knowledge obtained by the study of designed compounds that biomimic the $\mathrm{CuZ}$ center cannot be ignored, as they have provided valuable information about the structure and mechanistic properties of this center. New copper-sulfur compounds supported by nitrogen-donor ligands can provide insights into the binding and coordination of nitrous oxide to an electron-rich site as $\mathrm{CuZ}$, and allow estimation of thermodynamic parameters and redox potentials. Moreover, this approach enables low-temperature experiments in organic solvent to trap intermediate species in the $\mathrm{N}_{2} \mathrm{O}$ binding and reduction.

Some of these questions might be answered soon, since $\mathrm{N}_{2} \mathrm{OR}$ is the focus of many research groups, driven by the environmental significance of nitrous oxide as a greenhouse gas. During the revision of this manuscript, the crystallization of the "purple" form of $\mathrm{N}_{2} \mathrm{OR}$, which has the $\mathrm{CuZ}$ center in the $\left[2 \mathrm{Cu}^{2+}-2 \mathrm{Cu}^{+}\right]$state, was reported [91]. The CuZ center in this oxidation state has not yet been extensively characterized and its structural characterization will surely give rise to new and exciting challenges.

Acknowledgments This research was supported by Fundação para a Ciência e Tecnologia (FCT) grants PTDC/QUI/64638/2006 (to I.M.) and SFRH/BD/30414/2006 (to S.D.).

\section{References}

1. Ramirez BE, Malmstrom BG, Winkler JR, Gray HB (1995) Proc Natl Acad Sci USA 92:11949-11951

2. Ferguson-Miller S, Babcock GT (1996) Chem Rev 96:2889-2908

3. Zumft WG (1997) Microbiol Mol Biol Rev 61:533-616

4. Kaim W, Rall J (1996) Angew Chem Int Ed Engl 35:43-60

5. Malmström BG, Leckner J (1998) Curr Opin Chem Biol 2:286-292

6. Tsukihara T, Aoyama H, Yamashita E, Tomizaki T, Yamaguchi H, Shinzawa-Itoh K, Nakashima R, Yaono R, Yoshikawa S (1996) Science 272:1136-1144

7. Savelieff MG, Lu Y (2010) J Biol Inorg Chem 15:461-483

8. van Holde KE, Miller KI (1995) Adv Protein Chem 47:1-81

9. Solomon EI, Tuczek F, Root DE, Brown CA (1994) Chem Rev 94:827-856

10. Kosman D (2010) J Biol Inorg Chem 15:15-28

11. Dooley DM, McGuirl MA, Brown DE, Turowski PN, McIntire WS, Knowles PF (1991) Nature 349:262-264

12. Solomon EI, Sundaram UM, Machonkin TE (1996) Chem Rev 96:2563-2606

13. Balasubramanian R, Rosenzweig AC (2007) Acc Chem Res 40:573-580

14. Aboelella NW, Reynolds AM, Tolman WB (2004) Science 304:836-837

15. Moura I, Moura JJ (2001) Curr Opin Chem Biol 5:168-175

16. Tainer JA, Getzoff ED, Richardson JS, Richardson DC (1983) Nature 306:284-287

17. Malkin R, Malmström BG (1970) Adv Enzymol Relat Areas Mol Biol 33:177-244

18. Adman ET (1991) Adv Protein Chem 42:145-197

19. Solomon EI, Lowery MD, LaCroix LB, Root DE (1993) Methods Enzymol 226:1-33
20. Tavares P, Pereira AS, Moura JJ, Moura I (2006) J Inorg Biochem 100:2087-2100

21. Zumft WG, Kroneck PM (2007) Adv Microb Physiol 52:107-227

22. Richardson D, Felgate H, Watmough N, Thomson A, Baggs E (2009) Trends Biotechnol 27:388-397

23. Ahn J, Kim S, Park H, Rahm B, Pagilla K, Chandran K (2010) Environ Sci Technol 44:4505-4511

24. Iwasaki H, Saigo T, Matsubara T (1980) Plant Cell Physiol 21:1573-1584

25. Iwasaki H, Terai H (1982) J Gen Appl Microbiol Tokyo 28:189-193

26. Matsubara T, Zumft WG (1982) Arch Microbiol 132:322-328

27. Zumft WG, Matsubara T (1982) FEBS Lett 148:107-112

28. Coyle CL, Zumft WG, Kroneck PM, Korner H, Jakob W (1985) Eur J Biochem 153:459-467

29. Riester J, Zumft WG, Kroneck PM (1989) Eur J Biochem 178:751-762

30. McEwan AG, Greenfield AJ, Wetzstein HG, Jackson JB, Ferguson SJ (1985) J Bacteriol 164:823-830

31. Sato K, Okubo A, Yamazaki S (1998) J Biochem (Tokyo) 124:51-54

32. Snyder SW, Hollocher TC (1987) J Biol Chem 262:6515-6525

33. Teraguchi S, Hollocher TC (1989) J Biol Chem 264:1972-1979

34. Jones AM, Hollocher TC, Knowles R (1992) FEMS Microbiol Lett 92:205-209

35. Hulse CL, Averill BA (1990) Biochem Biophys Res Commun 166:729-735

36. SooHoo CK, Hollocher TC (1991) J Biol Chem 266:2203-2209

37. Berks BC, Baratta D, Richardson J, Ferguson SJ (1993) Eur J Biochem 212:467-476

38. Hole UH, Vollack KU, Zumft WG, Eisenmann E, Siddiqui RA, Friedrich B, Kroneck PM (1996) Arch Microbiol 165:55-61

39. Matsubara T, Sano M (1985) Chem Lett 14:1053-1056

40. Ferretti S, Grossmann JG, Hasnain SS, Eady RR, Smith BE (1999) Eur J Biochem 259:651-659

41. Prudencio M, Pereira AS, Tavares P, Besson S, Cabrito I, Brown K, Samyn B, Devreese B, Van Beeumen J, Rusnak F, Fauque G, Moura JJ, Tegoni M, Cambillau C, Moura I (2000) Biochemistry 39:3899-3907

42. Yamaguchi K, Kawamura A, Ogawa H, Suzuki S (2003) J Biochem (Tokyo) 134:853-858

43. Farrar JA, Thomson AJ, Cheesman MR, Dooley DM, Zumft WG (1991) FEBS Lett 294:11-15

44. Beinert H, Griffiths DE, Wharton DC, Sands RH (1962) J Biol Chem 237:2337-2346

45. Millett F, Darley-Usmar V, Capaldi RA (1982) Biochemistry 21:3857-3862

46. Kroneck PM, Antholine WA, Riester J, Zumft WG (1988) FEBS Lett 242:70-74

47. Kroneck PM, Antholine WA, Riester J, Zumft WG (1989) FEBS Lett 248:212-213

48. Jin H, Thomann H, Coyle CL, Zumft WG (1989) J Am Chem Soc 111:4262-4269

49. Dooley DM, McGuirl MA, Rosenzweig AC, Landin JA, Scott RA, Zumft WG, Devlin F, Stephens PJ (1991) Inorg Chem 30:3006-3011

50. Scott RA, Zumft WG, Coyle CL, Dooley DM (1989) Proc Natl Acad Sci USA 86:4082-4086

51. SooHoo CK, Hollocher TC, Kolodziej AF, Orme-Johnson WH, Bunker G (1991) J Biol Chem 266:2210-2218

52. Charnock JM, Dreusch A, Korner H, Neese F, Nelson J, Kannt A, Michel H, Garner CD, Kroneck PM, Zumft WG (2000) Eur J Biochem 267:1368-1381

53. Viebrock A, Zumft WG (1988) J Bacteriol 170:4658-4668

54. Zumft WG, Dreusch A, Lochelt S, Cuypers H, Friedrich B, Schneider B (1992) Eur J Biochem 208:31-40 
55. Dooley DM, Moog RS, Zumft WG (1987) J Am Chem Soc 109:6730-6735

56. Farrar JA, Zumft WG, Thomson AJ (1998) Proc Natl Acad Sci USA 95:9891-9896

57. Brown K, Tegoni M, Prudencio M, Pereira AS, Besson S, Moura JJ, Moura I, Cambillau C (2000) Nat Struct Biol 7:191-195

58. Brown K, Djinovic-Carugo K, Haltia T, Cabrito I, Saraste M, Moura JJG, Moura I, Tegoni M, Cambillau C (2000) J Biol Chem 275:41133-41136

59. Chen P, Gorelsky SI, Ghosh S, Solomon EI (2004) Angew Chem Int Ed 43:4132-4140

60. Rasmussen T, Berks BC, Sanders-Loehr J, Dooley DM, Zumft WG, Thomson AJ (2000) Biochemistry 39:12753-12756

61. Haltia T, Brown K, Tegoni M, Cambillau C, Saraste M, Mattila K, Djinovic-Carugo K (2003) Biochem J 369:77-88

62. Paraskevopoulos K, Antonyuk SV, Sawers RG, Eady RR, Hasnain SS (2006) J Mol Biol 362:55-65

63. Ghosh S, Gorelsky SI, Chen P, Cabrito I, Moura JJ, Moura I, Solomon EI (2003) J Am Chem Soc 125:15708-15709

64. Winkler JR (2000) Curr Opin Chem Biol 4:192-198

65. Farrar JA, Lappalainen P, Zumft WG, Saraste M, Thomson AJ (1995) Eur J Biochem 232:294-303

66. Antholine WE, Kastrau DH, Steffens GC, Buse G, Zumft WG, Kroneck PM (1992) Eur J Biochem 209:875-881

67. Oganesyan VS, Rasmussen T, Fairhurst S, Thomson AJ (2004) Dalton Trans 7:996-1002

68. Rasmussen T, Berks BC, Butt JN, Thomson AJ (2002) Biochem J 364:807-815

69. Chen P, DeBeer George S, Cabrito I, Antholine WE, Moura JJ, Moura I, Hedman B, Hodgson KO, Solomon EI (2002) J Am Chem Soc 124:744-745

70. Chen P, Cabrito I, Moura JJ, Moura I, Solomon EI (2002) J Am Chem Soc 124:10497-10507

71. Vaughan GA, Rupert PB, Hillhouse GL (1987) J Am Chem Soc 109:5538-5539

72. Tolman W (2010) Angew Chem Int Ed 49:1018-1024

73. Gorelsky SI, Ghosh S, Solomon EI (2006) J Am Chem Soc $128: 278-290$
74. St John RT, Hollocher TC (1977) J Biol Chem 252:212-218

75. Alefounder PR, Ferguson SJ (1982) Biochem Biophys Res Commun 104:1149-1155

76. Kristjansson JK, Hollocher TC (1980) J Biol Chem 255:704-707

77. Chan JM, Bollinger JA, Grewell CL, Dooley DM (2004) J Am Chem Soc 126:3030-3031

78. Alvarez ML, Ai J, Zumft W, Sanders-Loehr J, Dooley DM (2001) J Am Chem Soc 123:576-587

79. Ghosh S, Gorelsky SI, George SD, Chan JM, Cabrito I, Dooley DM, Moura JJ, Moura I, Solomon EI (2007) J Am Chem Soc 129:3955-3965

80. Dell'acqua S, Pauleta SR, Monzani E, Pereira AS, Casella L, Moura JJ, Moura I (2008) Biochemistry 47:10852-10862

81. Rasmussen T, Brittain T, Berks BC, Watmough NJ, Thomson AJ (2005) Dalton Trans 21:3501-3506

82. Richardson DJ, Bell LC, McEwan AG, Jackson JB, Ferguson SJ (1991) Eur J Biochem 199:677-683

83. Itoh M, Matsuura K, Satoh T (1989) FEBS Lett 251:104-108

84. Fujita K, Chan JM, Bollinger JA, Alvarez ML, Dooley DM (2007) J Inorg Biochem 101:1836-1844

85. Fujita K, Ijima F, Obara Y, Hirasawa M, Brown DE, Kohzuma T, Dooley DM (2009) J Biol Inorg Chem 14(Suppl 1):S11-S20

86. Zhang C, Jones AM, Hollocher TC (1992) Biochem Biophys Res Commun 187:135-139

87. Zhang CS, Hollocher TC (1993) Biochim Biophys Acta 1142:253-261

88. Wunsch P, Körner H, Neese F, van Spanning RJ, Kroneck PM, Zumft WG (2005) FEBS Lett 579:4605-4609

89. Bar-Nahum I, Gupta AK, Huber SM, Ertem MZ, Cramer CJ, Tolman WB (2009) J Am Chem Soc 131:2812-2814

90. Dell' acqua S, Pauleta SR, Paes de Sousa PM, Monzani E, Casella L, Moura JJ, Moura I (2010) J Biol Inorg Chem 15:967-976

91. Pomowski A, Zumft W, Kroneck P, Einsle O (2010) Acta Crystallogr Sect F Struct Biol Cryst Commun 66:1541-1543

92. Michalski WP, Hein DH, Nicholas DJD (1986) Biochim Biophys Acta 872:50-60 